\title{
ANALISIS PERMASALAHAN PENDIDIKAN ANAK USIA DINI DALAM MASYARAKAT INDONESIA
}

\author{
Lilis Suryani*
}

\begin{abstract}
Children are the future of a nation. This statement is not an exaggeration, it is the truth. Children would grow up and be potential leaders for their nation. The development of a country, then depends on them someday. So, it is important for us that we should pay more attention to their early childhood education right now. Paying more attention to this phase of education means improving the quality of human resources of a nation for the future. Unfortunately, few people are interested in becoming educators for early childhood education. Besides, most parents in Indonesia still do not realize how important early childhood education is for every individual child as well as for the future of our nation.
\end{abstract}

Keywords : competency, the quality of human resources, early childhood education, educators

\section{PENDAHULUAN}

Kemampuan yang handal tersebut diawali dengan kualitas sumber daya manusia (SDM) yang dihasilkan oleh pendidikan. Bila pendidikan berkualitas baik, maka dapat dipastikan SDM yang dihasilkanpun akan berkualitas baik. Peningkatan kualitas pendidikan secara luas, ditentukan oleh pendidikan awal yang diterima oleh SDM pada suatu bangsa. Pendidikan awal atau kita sebut disini Pendidikan Anak Usia Dini (PAUD) merupakan pondasi bagi perkembangan kualitas SDM selanjutnya. Karena itu peningkatan penyelenggaraan pendidikan anak usia dini di suatu negara memegang peranan yang vital untuk kemajuan bangsa tersebut di masa mendatang.

Arti penting mendidik anak sejak usia dini dilandasi dengan kesadaran bahwa masa kanak-kanak adalah masa keemasan (the golden years) ketika seluruh fungsi dan kemampuan anak sedang berkembang dengan sangat pesat. Kemampuan, yang menurut Vygotsky, masih merupakan potensial ini memerlukan kontribusi dari orang dewasa untuk memberikan stimulasi yang tepat agar kemampuankemampuan itu teraktualisasi dan berkembang dengan optimal.

Kesadaran akan pentingnya pendidikan anak usia dini tahun-tahun belakangan ini mendapatkan perhatian yang cukup menggembirakan dari berbagai kalangan masyarakat, dari pemerintah, pihak swasta, orang tua, akademisi, praktisi pendidik, agamawan dll.
Wujud kepedulian itu dimanifestasikan dengan terbentuknya berbagai lembaga pendidikan anak usia dini baik yang didirikan oleh masyarakat maupun pemerintah, seperti Bina Keluarga Balita, Posyandu, Tempat Penitipan Anak, Pusat-pusat PAUD, Kelompok Bermain, Taman Kanak-kanak, Raudatul Athfal, dll. Namun pembangunan pada sektor pendidikan anak usia dini ini tidak lepas dari berbagai kendala yang ditemui di lapangan, sehingga perkembangan PAUD di Indonesia belum dapat dikatakan telah optimal. Kendala-kendala tersebut berkaitan dengan kemampuan pemerintah dan masyarakat, pengelola dan mutu PAUD.

Menurut analisis penulis masalah-masalah itu adalah sebagai berikut.

1. Belum terpenuhinya kebutuhan masyarakat akan PAUD.

2. Kurangnya kualitas dan kuantitas guru/pamong PAUD.

3. Kurangnya mutu PAUD.

4. Kurangnya animo masyarakat/kesadaran orang tua tentang urgensi PAUD.

5. Kebijakan pemerintah tentang PAUD yang belum memadai.

Bila digambarkan dalam bentuk diagram maka kelima permasalahan tersebut dapat dilihat sebagai berikut. 


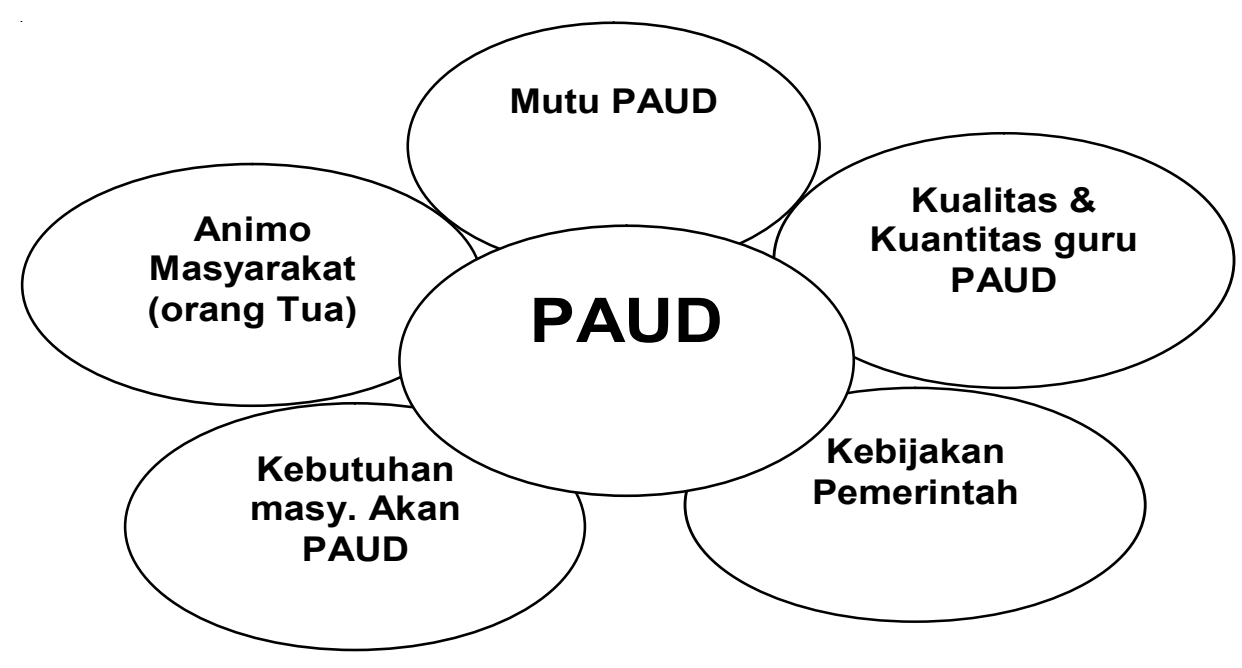

Gambar 1. Permasalahan PAUD di Indonesia

\section{PEMBAHASAN}

Belum Terpenuhinya Kebutuhan Masyarakat akan Pendidikan Anak Usia Dini

Pendidikan bagi anak-anak usia dini di Indonesia masih belum tergarap dengan baik. Padahal, pembinaan usia dini merupakan langkah strategis dan penting dalam membangun karakter dan kemampuan intelektual seseorang. Ini terjadi karena jumlah laju pertumbuhan anak usia dini di Indonesia tidak seimbang dengan laju pertumbuhan pembangunan sarana fisik institusi pra sekolah. Hasil analisis Tim Pendidikan Untuk Semua (Education for All) Indonesia tahun 2001 adalah sebagai berikut.

Tabel 1. Data Tim Education for All tahun 2001

\begin{tabular}{|c|c|c|c|}
\hline Usia Anak & Jumlah & Belum terlayani PAUD & Sudah terlayani PAUD \\
\hline $0-6$ th & 26 juta & 18,72 juta $(72 \%)$ & 7,28 juta $(28 \%)$ \\
\hline $4-6$ th & $12,6 j u t a$ & 8 juta $(63,4 \%)$ & 4,6 juta $(36,6 \%)$ \\
\hline
\end{tabular}

Tabel 2. Penyebaran anak usia dini yang terlayani PAUD

\begin{tabular}{|c|c|c|}
\hline Tempat & Prosentase & Jumlah \\
\hline Bina Kel.Balita & $9,60 \%$ & 2.496 .000 \\
\hline TK & $6,50 \%$ & 1.690 .000 \\
\hline RA & $1,40 \%$ & 364.000 \\
\hline KB & $0,13 \%$ & 33.800 \\
\hline TPA & $0.05 \%$ & 13.000 \\
\hline SD Kelas Awal & $9,90 \%$ & 2.574 .000 \\
\hline Jumlah & $27,58 \%$ & 7.170 .800 \\
\hline
\end{tabular}


Rasio layanan lembaga pendidikan anak usia dini dibandingkan anak yang belum terlayani adalah $1: 86$. Hal ini sungguh memprihatinkan. Selain itu, sekitar 186 ribu $(57,81$ persen) dari 335.845 anak usia dini (0-6) tahun di Daerah Istimewa Yogyakarta belum tertangani pendidikannya. Kondisi itu disebabkan oleh masih kurangnya tempat atau wadah pendidikan bagi anak usia dini. Dikhawatirkan apabila tidak segera ditangani, akan berpengaruh pada masa depan mereka. Demikian dikatakan Kepala Dinas Pendidikan DIY Suhadi.

Upaya yang telah dilakukan Pemerintah melalui Depdiknas sejauh ini adalah mendirikan pusat-pusat PAUD di daerah-daerah, termasuk di daerah tertinggal. Namun keberadaan pusat-pusat PAUD ini masih sangat minim dibandingkan dengan tingkat kebutuhan masyarakat.

Institusi anak usia dini belum merata/belum banyak ke daerah-daerah atau pelosok Indonesia sehingga anak usia dini berkembang hanya pada pusat pusat kota yang jumlahnya sangat terbatas ini, menjadi salah satu sebab terhambatnya pendidikan anak usia dini di masyarakat daerah. Selain itu, jenis pendidikan anak usia dini yang baru dikenal masyarakat adalah Taman Kanak-Kanak, sedangkan Kelompok Bermain (KB) kurang diminati dan Tempat Penitipan Anak (TPA) kurang sekali popularitasnya di mata masyarakat dan juga dibarengi dengan minimnya pengadaan institusinya secara fisik, begitu juga dengan bentuk-bentuk PAUD lainnya.

Pemerintah memegang peranan penting untuk membangun pendidikan anak usia dini di Indonesia. Sesuai dengan hak warga negara untuk mendapatkan pendidikan maka pengadaan kesempatan anak untuk mendapatkan pendidikan ini harus diperluas. Karenanya anggaran pembangunan untuk pengembangan PAUD di Indonesia harus ditingkatkan. Dengan anggaran pembangunan yang cukup maka penyelenggaraan PAUD dapat ditingkatkan secara merata di seluruh pelosok Indonesia, dan yang mengakibatkan meratanya pula kesempatan anak Indonesia untuk mendapatkan layanan pendidikan PAUD.

Secara moral dan legal negara memang berkewajiban menyelenggarakan pendidikan termasuk PAUD, namun pada kenyataannya kewajiban itu tidak hanya menjadi kewajiban negara tapi juga membutuhkan kontribusi masyarakat. Karena itu, peranan lembaga swasta untuk pendirian PAUD sangat diharapkan.

Urgensi PAUD sendiri sudah tidak diragukan lagi manfaatnya bagi peningkatan kualitas anak. Anak yang mendapat layanan PAUD akan lebih baik dari berbagai aspek perkembangannya. Oleh karenanya hubungan pengembangan PAUD dengan peningkatan kualitas anak sangat erat.

Menurut penulis, solusi yang dapat diupayakan untuk masalah ini antara lain adalah sebagai berikut.

1. Pemerintah selayaknya lebih memprioritaskan anggaran pembangunan PAUD diatas bidang pembangunan yang lain.

2. Pemerintah dapat mendukung dan bekerja sama dengan pihak swasta baik tingkat pusat maupun daerah untuk pembangunan PAUD berupa bantuan dana, supervisi, pembinaan guru dan sosialisasi acuan pembelajaran yang lebih intensif.

Guru/pamong anak usia dini masih kurang dari segi kualitas dan kuantitasnya

Secara kuantitas guru-guru/pamong yang berkecimpung dalam PAUD jauh lebih sedikit dibandingkan dengan jumlah guru-guru pada strata pendidikan yang lain (SD, SMP, SMU). Selain itu pun kualitasnyapun masih minim. Rektor Universitas Islam Bandung (Unisba), Prof HE Saefullah W, mengatakan hal tersebut. Menurutnya, jumlah tenaga kependidikan bagi pembinaan anak usia dini masih sangat kurang dibandingkan jumlah anak usia dini saat ini.

"Masih ada sekitar 15 juta anak usia dini yang belum tergarap aspek pendidikannya. Ini jumlah yang sangat besar, dan butuh tenaga kependidikan yang juga sangat banyak, tentunya dengan kemampuan memadai," ujarnya.

Kurang berminatnya lulusan atau masyarakat untuk jadi guru anak usia dini, menjadi kendala perkembangan PAUD di Indonesia. Hal ini disebabkan, secara filosofi manusia Indonesia kurang mengenal pendidikan anak usia dini, sehingga apa yang tercermin dari moralitas manusia dewasa Indonesia saat ini pada umumnya adalah kurangnya rasa tanggung jawab, toleransi, disiplin, kejujuran dan kepekaan terhadap sesamanya.

Kurang berminatnya masyarakat untuk menjadi guru PAUD juga karena profesi guru, termasuk guru PAUD, masih identik dengan pendapatan yang minim. Hanya guru di kota yang mempunyai kesempatan mendapatkan kesempatan yang lebih baik daripada guru di desa. Karena itu masyarakat yang berprofesi sebagai guru lebih terpusat di kota sehingga daerah mengalami kekurangan guru. Hal ini berlaku juga untuk guru PAUD.

Kurang berminatnya masyarakat untuk menjadi guru PAUD dengan sendirinya mengakibatkan kurang berminatnya pihak swasta untuk mendirikan institusi kependidikan untuk mencetak guru-guru PAUD. Kondisi 
ini semakin membuat Indonesia kekurangan guru PAUD dari segi kuantitas.

Walaupun secara khusus dapat diamati, saat ini mulai bertumbuhnya minat untuk mencetak tenagatenaga PAUD, namun masih terbatas pada lingkungan akademisi pendidikan tinggi yang memang secara keilmuan menyadari betapa pentingnya PAUD

Di satu sisi, dari segi kualitaspun guru PAUD Indonesia masih rendah mutunya. Misalnya, Iulusan SMU atau SMP mengajar TK/PAUD atau bahkan tidak berpendidikan sama sekali (dari observasi penulis, di salah satu desa di Bogor terdapat guru TK lulusan SD), artinya guru anak usia dini ini kurang kompeten di bidangnya. Kondisi ini membuat merosotnya mutu pendidikan PAUD yang berimbas negatif pada pembentukan kualitas anak.

Agar kemampuan tenaga kependidikan itu memadai, lembaga pendidikan guru anak usia dini harus pula memberikan beragam aspek ilmu pengetahuan sesuai dengan karakter perkembangan anak. Selain aspek pendidikan, juga periu diperhatikan pengetahuan penunjang lainnya seperti kesehatan dan psikologi anak.

Mengajar anak usia dini oleh masyarakat dianggap sebagai pengajaran yang mudah, sehingga banyak guru anak usia dini yang kurang maksimal dalam memberikan pendidikan bagi anak usia dini. Mereka masih banyak tidak mengetahui perkembangan anak, pembelajaran bagi anak usia dini dan stimulasinya sehingga sasaran pendidikan anak dirasakan kurang efektif dan mengena.

Untuk menghasilkan pendidikan yang bermutu tentulah dibutuhkan guru yang bermutu pula. Sebaliknya bila kualitas guru rendah maka kualitas anak didik pun akan rendah.

PAUD bukanlah bidang yang dapat dianggap ringan. Perlu orang yang kompeten dibidangnya untuk mendidik anak. Karena itu, guru PAUD perlu mempunyai latar pendidikan yang sesuai dengan PAUD, agar dapat mengajar dengan baik dan memaksimalkan potensi potensi anak.

Peningkatan kualitas anak usia dini juga dipengaruhi oleh faktor kuantitas guru. Rasio perbandingan anak dan guru yang tak seimbangkan akan menimbulkan masalah baru. Satu guru yang mengajar 30 anak tentu tidak bisa memperhatikan proses belajar anak anak tersebut satu persatu secara intensif. Dengan sendirinya hat ini akan berakibat pada penurunan kualitas anak didik.

Menurut penulis, solusi yang dapat diupayakan untuk masalah ini antara lain sebagai berikut.
1. Perlu adanya kenaikan pendapatan guru anak usia dini oleh pemerintah maupun swasta agar menarik minat masyarakat untuk menjadi guru anak usia dini.

2. Pemerintah dapat mengalokasikan dana anggaran pembangunan yang lebih besar untuk menaikan pendapatan guru PAUD.

3. Dengan bertumbuhnya minat masyarakat untuk berprofesi sebagai guru/pamong anak usia dini, pihak swasta diharapkan dapat lebih berkontribusi untuk mendirikan institusi pendidikan untuk mencetak guru-guru anak usia dini baik di tingkat pusat maupun daerah.

4. Institusi prasekolah negeri dan swasta perlu menetapkan peraturan bahwa pendidikan minimal guru anak usia dini adalah Diploma II dalam bidangnya dan akan lebih baik lagi bila S-1.

5. Berdirinya PTK-PNF dibawah Dirjen PLSP Depdiknas diharapkan dapat turut mendukung bagi perkembangan dan kemajuan guru/pamong PAUD baik secara kualitas maupun kuantitas.

6. Perlunya kerja sama yang saling mendukung antara pemerintah (dalam hal ini PTK-PNF) dengan organisasi profesi PAUD (dalam hal ini HIMPAUDI baik tingkat pusat maupun daerah) untuk bersamasama meningkatkan kualitas dan kuantitas guru/ pamong PAUD secara merata di seluruh wilayah Indonesia.

Kurangnya kesadaran orangtua terhadap urgensi pendidikan anak usia dini

Salah satu faktor yang menyebabkan lambatnya pertumbuhan anak usia dini adalah aspirasi masyarakat yang rendah terhadap anak usia dini, banyak orang tua beranggapan masa sekolah adalah berawal belajar sekolah formal di kelas satu SD, sehingga lima tahun pertama berlalu begitu saja di rumah tanpa stimulasi yang optimal dari orang tua.

Peraturan Pemerintah No. 27 yang menyatakan bahwa pendidikan pra sekolah bukan syarat masuk ke $\mathrm{SD}$, turut memperendah aspirasi orang tua terhadap urgensi pendidikan anak usia, karena mendapat tanggapan salah dari orang tua pada umumnya yang mengartikan pendidikan bagi anak usia dini tidaklah penting. Selain itu pendidikan anak usia dini di Indonesia masih mahal dan tidak terjangkau oleh penduduk yang rata-rata kesejahteraannya masih rendah.

Kebanyakan orang tua tidak mempunyai wawasan tentang perkembangan anak yang cukup sehingga mereka banyak yang tidak menguasai pendidikan anak usia dini di rumah. Mereka juga tidak mendapatkan pendidikan khusus tentang anak usia dini.

Jurnal IImiah VISI PTK-PNF - Vol. 2, No.1 - 2007 45 
Padahal seperti yang kita tahu, keluarga adalah lingkungan pertama dan utama yang akan memberikan pijakan dasar bagi perkembangan anak tersebut selanjutnya. Sebagian besar orangtua, karena faktor kekurangpahaman, kesibukan dan lainnya, banyak melalaikan tahun-tahun penting pertama dalam kehidupan anak. Terutama orangtua (ayah dan ibu) yang sibuk mencari nafkah baik di kota maupun di desa, tidak memberikan alternatif sebagai pengganti pendidikan bagi sang anak. Hal itu disebabkan kurangnya kesadaran terhadap urgensi pendidikan anak usia dini.

Hal yang perlu disadari oleh orangtua adalah bahwa anak yang mendapat pelayanan pendidikan anak usia dini, perkembangan aspek-aspek fisik dan psikisnya akan meningkat dan berkembang dengan lebih optimal dibandingkan anak yang tidak melalui PAUD. Hal ini sesuai dengan hasil penelitian penulis dalam penulisan skripsi S-1 di IKIP Jakarta (1998).

Menurut penulis, solusi yang dapat diupayakan untuk masalah ini antara lain sebagai berikut.

1. Pemerintah maupun swasta mengadakan institusi pendidikan bagi orangtua tentang anak usia dini (parenting school) yang dapat terjangkau oleh semua kalangan. Bahkan di beberapa negara maju, parenting school ini menjadi persyaratan pemerintah untuk diikuti bagi para pasangan muda yang sedang mengurus legalisasi pernikahan.

2. Pembinaan PAUD sampai ke pelosok-pelosok daerah, tidak hanya di Posyandu, tetapi juga dengan sistem door to door/jemput bola dan terjun langsung ke masyarakat. Program ini dapat dilaksanakan secara kolaboratif antara Depdiknas, Depsos, Depag wilayah setempat, Pemda dan tokoh-tokoh masyarakat di daerah tersebut dengan kader-kader yang terpilih dan mampu mengemban tugas ini.

3. Mengadakan lembaga PAUD yang terjangkau bahkan cuma-cuma untuk masyarakat kurang mampu, dengan subsidi dari aparat pemerintah dan masyarakat setempat. Dalam hal ini, inisiatif mengadakan TK Keliling yang dilakukan oleh Kelompok Sosial Pecinta Anak Universitas Negeri Jakarta, patut diikuti.

Mutu pendidikan dan anak usia dini masih rendah

Usia di bawah lima tahun (balita) adalah usia yang paling peka atau paling menentukan dalam pembentukan karakter dan kepribadian seseorang. Termasuk juga pengembangan intelegensi dan aspekaspek lain hampir seluruhnya terjadi pada usia di bawah lima tahun. Kalau seseorang sudah terlanjur menjadi pelaku kejahatan/tindak kriminal, maka pendidikan yang telah didapat orang tersebut boleh dikatakan tidak berarti. Sebagaimana halnya sebatang pohon bambu, setelah tua susah dibengkokkan.

Anak-anak pada usia di bawah lima tahun memiliki potensi intelegensi (potential intelegence) yang luar biasa. Namun, pada umumnya para orangtua dan guru hanya bisa mengajarkan sesuatu sedikit saja pada anak-anak. Sesungguhnya anak-anak usia muda tidak complicated (ruwet) dalam belajar, tetapi orangtua atau guru yang bermasalah. Pada umumnya kita selalu menyalahkan anak-anak apabila tingkah laku mereka tidak seperti yang kita inginkan. Hal ini lebih banyak disebabkan kurangnya pengetahuan dan pemahaman kita terhadap perkembangan anak, sehingga kita sering memperlakukan anak dengan kurang tepat.

Anak-anak memiliki rasa ingin tahu yang luar biasa dan kemampuan untuk menyerap informasi yang sangat tinggi. Kebanyakan orang tidak mengenali dan memahami kemampuan 'magic' yang ada pada anakanak. Mereka hanya bisa berkata, "Saya tahu anakanak belajar lebih cepat", tetapi mereka tidak tahu "seberapa cepat anak-anak bisa belajar". Karena keterbatasan pengetahuan dan kemampuan orang tua dan guru-guru maka potensi luar biasa yang ada pada setiap anak sebagian besar tersia-siakan.

Kita lihat perkembangan pendidikan anak usia dini yang telah tumbuh dengan pesat di luar negeri, menghasilkan anak anak yang mempunyai karakteristik: kritis, mandiri, aktif, kreatif, logika berfikir tinggi dan berani menampilkan diri. Hal ini berbanding terbalik dengan anak usia dini di Indonesia. Di Indonesia PAUD belum begitu berhasil sehingga berpengaruh secara signifikan pada kualitas anak usia dini Indonesia pada umumnya yang mempunyai karakteristik: kurang kritis, kurang mandiri, pasif, kurang kreatif, logika berfikir rendah dan kurang berani menampilkan diri.

Peningkatan kualitas anak melalui pendidikan tidak terlepas dari tersedianya kerangka penyelenggaraan pendidikan yang baik secara keseluruhan, yaitu falsafah dan tujuan pendidikan, luas/dalamnya materi, metode dan teknik membelajarkan, media pengajaran, interaksi/kegiatan pembelajaran dan sarana/fasilitas yang mendukung. Faktor-faktor ini masih kurang bermutu dalam pembelajaran PAUD di Indonesia. Dengan sendirinya kualitas anak usia dini di Indonesia masih kurang seperti karakteristik di atas.

Bila faktor-faktor tersebut dirancang dengan baik dan cermat maka, dapat dipastikan kualitas pendidikan anak usia dini pun akan meningkat, dan bila faktor-faktor pendidikan itu mengalami perbaikan 
menyeluruh akan mempengaruhi kualitas pendidikan anak pada umumnya seperti anak menjadi kritis, mandiri, aktif, kreatif, logika berfikir tinggi dan berani rnenampilkan diri.

Menurut penulis, solusi yang dapat diupayakan untuk masalah ini antara lain adalah sebagai berikut.

1. Pemerintah diharapkan memperbaiki acuan pembelajaran PAUD terutama perluasan dan pendalaman materi. Acuan menu pembelajaran generik yang menjadi pedoman PAUD selama ini diharapkan dapat terus direvisi. Pengembangan dan inovasi metode pendidikan untuk PAUD, seperti Beyond Centre and Circle Time (BCCT) diharapkan dapat terus ditingkatkan dan disosialisasikan secara merata ke seluruh instansi PAUD, terutama ke daerah-daerah.

2. Pemerintah maupun institusi prasekolah swasta dapat secara kreatif memperkaya faktor-faktor pembelajaran yang telah berjalan selama ini seperti:

a. merevisi tujuan pembelajaran yang lebih mengarahkan agar anak lebih kritis, mandiri, aktif, kreatif, logika berfikir tinggi dan berani menampilkan diri;

b. memperkaya materi pembelajaran agar lebih menarik anak untuk bereksplorasi dalam lingkungannya;

c. metode disesuaikan dengan karakteristik anak yang aktif dan kreatif;

d. media diusahakan semenarik mungkin, dengan memanfaatkan sumber-sumber lingkungan yang ada;

e. kualitas interaksi guru dan siswa harus mengundang minat anak untuk belajar; dan

f. sarana yang lebih dapat mengakomodasi kebutuhan PAUD.

3. Pemerintah maupun institusi prasekolah swasta dapat melakukan studi banding pada prasekolah yang dianggap telah berhasil di dalam maupun di luar negeri dan mengadaptasi sistem pendidikannya, tentu saja terlebih dahulu dengan kajian yang mendalam dan disesuaikan dengan kondisi dan budaya masyarakat Indonesia.

Kebijakan Pemerintah saat ini kurang mendukung perkembangan pendidikan anak usia dini

Penulis melihat kebijakan Pemerintah ini dari dua sudut yaitu alokasi dana pendidikan dan kebijakan Peraturan Pemerintah tentang PAUD. Alokasi dana pendidikan sebesar Rp. 17 triliun tidak memadai untuk negeri sebesar Indonesia. Pemerintah seharusnya mengeluarkan anggaran yang lebih besar untuk pendidikan, yaitu sebesar Rp. 80 triliun. " Lebih baik kita menunda membayar utang luar negeri dari pada kita tunda mendidik anak-anak kita dengan baik", kata Marwah Daud Ibrahim dari F-PG ketika Dengar Pendapat antara Dirjen Baga Islam Depag, Dirjen Dikdasmen, dan Dirjen Pendidikan Luar Sekolah (PLSP) dengan Komisi VI DPR. Lebih lanjut anggota dari Fraksi Partai Golkar itu mengatakan bahwa dirinya sangat berharap pada pendidikan, karena seluruh proses bangsa dibangun lewat pendidikan. Artinya banyak hal yang tidak dibiasakan di rumah tapi kemudian terbiasakan lewat proses sekolah. Orang yang tidak produktif di rumah bisa produktif lewat proses sekolah.

Anggota Fraksi Golkar lainnya, Agusman Sutan Basa, bahkan menyarankan untuk menambah anggaran pendidikan dibuat RUU pajak pendidikan tersendiri, yaitu dengan menambahkan berapa persen dari seluruh jenis pajak yang ada. Aspirasi para tokoh ini mencerminkan betapa perlunya pemerintah memperbesar anggaran untuk pendidikan, termasuk PAUD di dalamnya. Karena hal itu sama dengan kita menanam investasi jangka panjang yang akan kita tuai di masa depan berupa kemajuan bangsa ke arah yang lebih maju.

Dari sisi kebijakan, Peraturan Pemerintah No. 27 yang masih berlaku menyatakan bahwa pendidikan pra sekolah bukan syarat masuk ke SD merupakan PP yang kurang berpihak bagi berkembangnya PAUD di Indonesia. PP ini berdampak luas pada berbagai aspek seperti efek domino (saling berpengaruh dan berkaitan), yaitu orang tua menjadi kurang memprioritaskan PAUD bagi anak balitanya, namun langsung memasukkannya ke SD, kurangnya minat pemerintah dalam mendirikan institusi lembaga PAUD (misalnya TK negeri pada jalur formal) tidak seperti halnya pembangunan SD-SD negeri yang begitu digalakkan sampai ke daerah-daerah, lebih jauh lagi mengakibatkan minimnya permintaan pemerintah atas formasi guru-guru untuk TK negeri maupun swasta (apalagi guru/pamong PAUD) sebagai Pegawai Negeri Sipil, yang pada gilirannya hal ini akan mengurangi minat masyarakat untuk menjadi guru TK/guru PAUD karena kurang berpeluang untuk menjadi Pegawai Negeri Sipil melalui jalur ini, dan akhirnya akan mengakibatkan masalah kurangnya kuantitas guru PAUD yang berakibat tidak terlayaninya anak-anak usia dini yang membutuhkan pendidikan.

Dengan terakomodasinya masalah PAUD dalam UU Sisdiknas No. 20 Tahun 2003, Pasal 28, diharapkan dapat melahirkan Peraturan Pemerintah tentang pra sekolah/PAUD baru yang lebih berpihak pada legalitas

Jurnal IImiah VISI PTK-PNF - Vol. 2, No.1 - 2007 
eksistensi PAUD itu sendiri di Indonesia beserta seluruh perangkat pendukungnya.

Menurut penulis, solusi yang dapat diupayakan untuk masalah ini antara lain:

1. Pemerintah hendaknya mengubah kebijakan agar pendidikan pra sekolah/PAUD menjadi kondisi yang lebih diutamakan untuk masuk SD, mengingat pentingnya pendidikan prasekolah bagi perkembangan anak selanjutnya;

2. penganggaran porsi dana yang lebih besar untuk pembangunan PAUD di Indonesia;

3. meningkatkan pendapatan guru anak usia dini baik di tingkat pusat ataupun daerah;

4. membangun infrastruktur (gedung-gedung) pusat pendidikan anak usia dini secara merata di Indonesia; dan
5. membuka peluang dan pengangkatan guru/pamong anak usia dini sebagai Pegawai Negeri Sipil untuk menarik minat masyarakat menjadi guru PAUD. Selain itu juga dengan status PNS pembinaan pemerintah terhadap guru PAUD diharapkan menjadi lebih terarah dan intensif.

Melihat kondisi dan permasalahanpermasalahan PAUD di atas, sistem penanganan terhadap pendidikan anak usia dini di Indonesia selama ini perlu ada perbaikan. Paling tidak perlu adanya terobosan baru untuk memberdayakan dan mensinergikan semua potensi yang telah ada di masyarakat dalam rangka tercapainya layanan tumbuh kembang anak secara utuh, menyeluruh dan terintegrasi.

\section{KESIMPULAN}

Perkembangan PAUD di Indonesia saat ini meningkat secara signifikan dan perlu terus ditingkatkan baik kualitas maupun kuantitasnya di masa yang akan datang. Membenahi masalah-masalah PAUD memerlukan proses yang terus diupayakan dan good will dari semua pihak.

Berdasarkan kondisi dan permasalahanpermasalahan PAUD, sistem penanganan terhadap pendidikan anak usia dini di Indonesia selama ini memerlukan perbaikan. Terobosan baru perlu dirintis untuk memberdayakan dan mensinergikan semua potensi yang ada di masyarakat untuk mewujudkan layanan tumbuh kembang anak yang utuh, menyeluruh, dan terintegrasi.

Bila tidak dibarengi dengan upaya memperbaiki kondisi, bukannya tidak mungkin perkembangan PAUD di Indonesia semakin menimbulkan masalah-masalah baru yang tambal sulam dan semakin rumit penanganannya. Dalam hal ini yang paling dirugikan adalah anak-anak Indonesia sendiri sebagai tunas bangsa mendatang.

\section{DAFTAR PUSTAKA}

Jalal, F. (2004). Arah kebijakan nasional PAUD. Materi Seminar dan Lokakarya Nasional PAUD, UNJ 9 Oktober 2004. Jakarta: Tidak diterbitkan.
(2006). Undang-undang no. 20 tahun 2003 tentang sistem pendidikan nasional. Jakarta: Depdiknas.

Media Indonesia 13 Oktober 2003 